\title{
ORIGINAL ARTICLE \\ Identification and molecular characterization of oat peptides implicated on coeliac immune response
}

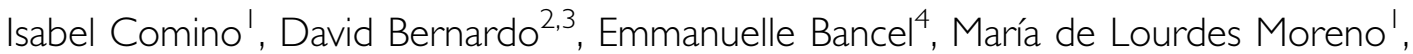 \\ Borja Sánchez ${ }^{5}$, Francisco Barro ${ }^{6}$, Tanja Šuligoj ${ }^{7}$, Paul J. Ciclitira ${ }^{7}$, Ángel Cebolla ${ }^{8}$, \\ Stella C. Knight ${ }^{2}$, Gérard Branlard ${ }^{4}$ and Carolina Sousa'* \\ 'Departamento de Microbiología y Parasitología, Facultad de Farmacia, Universidad de Sevilla, Sevilla, Spain; \\ ${ }^{2}$ Gastroenterology Unit, Antigen Presentation Research Group, Imperial College London \& St Mark's Hospital, Harrow, \\ United Kingdom; 'Hospital Universitario de La Princesa and Instituto de Investigación Sanitaria Princesa (IIS-IP), Centro \\ de Investigación Biomédica en Red de Enfermedades Hepáticas y Digestivas (CIBEREHD), Madrid, Spain; ${ }^{4}$ INRA UMR- \\ 1095, Clermont-Ferrand, France; ${ }^{5}$ Nutrition and Bromatology Group, Department of Analytical and Food Chemistry, \\ Food Science and Technology Faculty, University of Vigo-Ourense Campus, Ourense, Spain; ${ }^{6}$ Instituto de Agricultura \\ Sostenible (CSIC), Córdoba, Spain; 'Division of Diabetes and Nutritional Sciences, King's College London, \\ Gastroenterology, The Rayne Institute, St Thomas' Hospital, London, United Kingdom; ${ }^{8}$ Biomedal S.L., Sevilla, Spain
}

\section{Abstract}

Background: Oats provide important nutritional and pharmacological properties, although their safety in coeliac patients remains controversial. Previous studies have confirmed that the reactivity of the anti-33-mer monoclonal antibody with different oat varieties is proportional to the immune responses in terms of T-cell proliferation. Although the impact of these varieties on the adaptive response has been studied, the role of the dendritic cells (DC) is still poorly understood. The aim of this study is to characterize different oat fractions and to study their effect on DC from coeliac patients.

Methods and results: Protein fractions were isolated from oat grains and analyzed by SDS-PAGE. Several proteins were characterized in the prolamin fraction using immunological and proteomic tools, and by Nano$L C$-MS/MS. These proteins, analogous to $\alpha$ - and $\gamma$-gliadin-like, showed reactive sequences to anti-33-mer antibody suggesting their immunogenic potential. That was further confirmed as some of the newly identified oat peptides had a differential stimulatory capacity on circulating DC from coeliac patients compared with healthy controls.

Conclusions: This is the first time, to our knowledge, where newly identified oat peptides have been shown to elicit a differential stimulatory capacity on circulating DC obtained from coeliac patients, potentially identifying immunogenic properties of these oat peptides.

Keywords: coeliac disease; oats; immune response; gluten-free diet

Received: 7 November 2015; Revised: 6 December 2015; Accepted: 7 December 2015; Published: 5 February 2016

$\mathrm{C}$ oeliac disease (CD) is an autoimmune disorder developed in genetically (HLADQ2/8) predisposed individuals and caused by a permanent intolerance to gluten contained in some cereals, such as wheat, rye, and barley, that lead to a chronic inflammation of the small intestine (1-3).

The most accepted model for explaining CD immunopathogenesis is the two-signal model (4) characterized by a first innate immune response followed by a secondary antigen-specific adaptive response. Some peptides like the 19-mer gliadin peptide trigger an innate immune response (5) mainly characterized by the production of IL-15 by epithelial cells. The result is the disruption of the epithelial barrier, by increasing the permeability and inducing enterocyte apoptosis (6). As a consequence, immunoadaptive peptides, like the 33-mer gliadin peptide, can now reach the lamina propria where they are deaminated by the enzyme tissue transglutaminase. Such deamidation provides a negative load to gliadin peptides and hence enhance their affinity to fit in the HLA-DQ2/8 bound, which is also the 'susceptibility gene' in $\mathrm{CD}$, expressed on the surface of dendritic cells (DC) (7-9). DC are indeed the most potent antigen-presenting cells of the immune system as they promote differentiation of pro-inflammatory antigen-specific effector T-cell at the time that they also direct them to the target tissue via homing marker 
imprinting $(10,11)$. DC are therefore central in $\mathrm{CD}$ pathogenesis as they present a gluten antigen to T-cells (12) driving progression of the pro-inflammatory antigenspecific adaptive immune response which will turn into the symptomatology of the disease.

The gluten-free diet (GFD) is the basis of all the present treatments for $\mathrm{CD}$, after which the immune response is abrogated leading to clinical remission of the disease (13, 14). Recently, the gluten-free products market has witnessed a revolution due to an increased incidence of $\mathrm{CD}$ coupled with the fact that it is not only coeliac and glutensensitive patients consuming these products but also individuals not affected by those pathologies (15). Therefore, oats are of particular interest to all GFD consumers because they could improve the nutritional value of the GFD given their rich nutritional value and a considerably high protein concentration. Oats also contain a number of important minerals, lipids, $\beta$-glucan, a mixed-linkage polysaccharide, which forms an important part of oat dietary fiber, and also contains various other phytoconstituents. Finally, oats also have different pharmacological activities including antioxidant, anti-inflammatory, antidiabetic, anticholesterolemic, and many others. Therefore, all these properties have led to wider appreciation of oats as valuable human food (16).

Studies on the suitability of oats for patients with CD showed contradictory results. While some studies suggested that oats are safe for CD patients (17-20), others have revealed that oats can trigger an immune reaction in these patients (18,21-23), including activation of mucosal T-cells and subsequent gut inflammation ultimately leading to villous atrophy (22). Indeed, CD patients have circulating anti-avenin antibodies $(24,25)$, while a recent study revealed that dietary oats altered the mRNA immune status of the intestinal mucosa suggesting T-cell activation and leaky tight junctions (26). These contradictory results regarding oats safety for $\mathrm{CD}$ patients might be explained by the fact that the oat varieties used in the different studies were different. Oats include numerous varieties, differing in the prolamin genes and hence in the resulting amino acid sequences showing different immunoreactivities associated with toxic prolamins $(27,28)$. In previous studies, our group has reported the utility of the G12 monoclonal antibody (moAb) against the main immunogenic epitope of the $\alpha-2$ gliadin, 33-mer peptide, for detecting oat varieties that are potentially toxic for $\mathrm{CD}$ patients. Indeed, the reactivity with the anti-33-mer moAb of the different oat varieties correlated with T-cell proliferation and interferon gamma production of blood T-cells isolated from such patients (29).

In the present study, we have characterized the different protein fractions of oat prolamins and have identified several reactive sequences to anti-33-mer moAb, analogous to $\alpha$ - and $\gamma$-gliadin-like, with immunogenic potential for $\mathrm{CD}$ patients. Moreover, some of the peptides from these subunits, obtained from Nano-LC-MS/MS data, induced specific activation of circulating DC obtained from $\mathrm{CD}$ patients on the GFD, as opposed to those from healthy controls (HC), confirming therefore their immunogenic potential.

\section{Materials and methods}

\section{Oat sample preparation}

Oats (Avena sativa L.) from cultivars designated OE717, OA729, OM719, OC723, OH727, and OL715 (obtained from Spanish and Australian commercial sources) were used in this work. These cultivars were chosen based on their previously reported CD toxicity (29).

\section{DNA extraction}

DNA extraction from oat seeds was performed using a modified cetyltrimethylammonium bromide (CTAB) method. DNA concentrations were determined by UV absorption. The purity of the DNA solution was assessed by the $260 / 280 \mathrm{~nm}$ absorption ratio. Oligonucleotides from wheat, barley, rye, and oats were used. This protocol and oligonucleotides have been characterized in detail in previous studies from our laboratory (29).

\section{Protein extraction and quantification}

Oat flours were prepared by grinding the dehusked kernels. Wholemeal flour $(100 \mathrm{mg})$ was used for the sequential extraction of the albumins, globulins, avenins, and glutenins according to Osborne (30) and Marion et al. (31).

\section{Albumin extraction}

The albumins were extracted with cold water with continuous mixing at $4^{\circ} \mathrm{C}$ for $90 \mathrm{~min}$. The mixture was centrifuged $(8,000 \mathrm{~g}, 20 \mathrm{~min})$ and the proteins in the supernatant were precipitated with two volumes of acetone at $-20^{\circ} \mathrm{C}$. The pellet was then washed three times with acetone and dried at room temperature.

\section{Globulin extraction}

Globulins were extracted from the pellet with a salt solution (Tris- $\mathrm{HCl} 50 \mathrm{mM}, \mathrm{NaCl} 1 \mathrm{M}, \mathrm{pH} 8.5$ ) in continuous mixing at $4^{\circ} \mathrm{C}$ for $1 \mathrm{~h} 30 \mathrm{~min}$. Similarly, the mixture was centrifuged and the proteins in the supernatant were recovered with acetone.

\section{Avenins extraction}

To extract avenins, three washes were performed with cold water on the pellet described above for $5 \mathrm{~min}$ with continuous vortexing. The samples were treated with $70 \%$ ethanol $(\mathrm{v} / \mathrm{v})$ for $60 \mathrm{~min}$ with continuous mixing, followed by centrifugation $(10,000 \mathrm{~g}, 5 \mathrm{~min})$. This step was repeated three times to remove most of the avenins. The supernatants were pooled and incubated overnight at $65^{\circ} \mathrm{C}$ to recover the avenins. 


\section{Glutenins extraction}

The glutenins in the pellet were extracted and reduced with $50 \%$ propanol-1-ol solution containing $1 \%$ w/v dithiothreitol (DTT) for $30 \mathrm{~min}$ with continuous mixing at $65^{\circ} \mathrm{C}$, followed by centrifugation $(10,000 \mathrm{~g}, 5 \mathrm{~min})(32)$.

\section{SDS-PAGE}

Proteins (albumins, globulins, avenins, and glutenins) were resuspended in SDS-polyacrylamide gel electrophoresis (PAGE) loading buffer ( $45 \mathrm{mM}$ Tris-HCl, $\mathrm{pH} 6.8,50 \mathrm{mM}$ DTT, $1 \%$ SDS, $10 \%$ glycerol, $0.001 \%$ bromophenol blue). Protein concentration was determined by Bradford assay (33). Proteins were separated by SDS-PAGE using 12.5\% polyacrylamide gel using a Hoefer tank (GE Healthcare, Little Chalfont, Buckinghamshire, UK). Gels were stained with Coomassie Brilliant Blue (CBB).

\section{Acid PAGE}

In order to identify a large number of avenins according to their relative mobility, an acid PAGE (A-PAGE) was performed following the method of Branlard et al. (34).

\section{2-DE}

For further characterization of avenins, two biological extracts with two replicates per extract were used. Isoelectric focusing (IEF) was performed using the IPGPhor II apparatus (GE Healthcare) on $13 \mathrm{~cm}$ Immobiline dry strips of 3-10 linear $\mathrm{pH}$ gradients. Passive re-hydration was performed overnight in a solution containing $7 \mathrm{M}$ urea, $2 \mathrm{M}$ thiourea, $70 \mathrm{mM}$ DTT, $1 \%$ IPG buffer $(\mathrm{pH}$ 3-10), 4\% CHAPS, $0.34 \%$ anti-protease, and $100 \mu \mathrm{g}$ (analytical gel) or $1 \mathrm{mg}$ (preparative gel) of the protein extract. IEF was carried out by applying a cumulative voltage of 30 and $60 \mathrm{kVh}$ for analytical and preparative gel, respectively.

Following IEF, proteins were reduced for $15 \mathrm{~min}$ in an equilibration buffer containing $0.05 \mathrm{M}$ Tris- $\mathrm{HCl}(\mathrm{pH} 8.8)$, $6 \mathrm{M}$ urea, $30 \%$ glycerol, $2 \%$ SDS, and $1 \%$ DTT, followed by alkylation for $15 \mathrm{~min}$ in the same buffer containing $2.5 \%$ iodoacetamide instead of DTT. The second dimension was performed using SDS-PAGE gels (12\% T, 2.1\% C) sealed with $0.5 \%$ agarose in SDS buffer on Hoefer vertical system (GE Healthcare). The migration conditions were $10 \mathrm{~mA} / \mathrm{gel}$ for first $30 \mathrm{~min}$ then $35 \mathrm{~mA} / \mathrm{gel}$ until the exit of the dye front. Gels were stained with CBB.

\section{Immunoblotting}

For immunoblot analysis, protein samples were separated on a $12.5 \%$ SDS-PAGE or a 2-DE gel and then transferred onto a nitrocellulose membrane using a Hoefer TE77 semidry transfer blotter. The blotted membrane was incubated for $60 \mathrm{~min}$ at room temperature in blocking buffer consisting of $10 \mathrm{mM}$ Tris- $\mathrm{HCl}(\mathrm{pH} 7.6), 150 \mathrm{mM}$ $\mathrm{NaCl}, 0.01 \%$ Tween 20 and 5\% skimmed milk and then exposed to G12 moAb.
Anti-mouse IgG alkaline phosphatase A3562 and kit SIGMA fast (ref F4523) were used for detection according to the manufacturer instructions.

Gel images of 300 dpi and 16-bit grayscale pixel depth were obtained with G-800 (GE Healthcare) scanner and were analyzed using SameSpots v3.2 (Nonlinear Dynamics, Newcastle, UK). SameSpots applies highly accurate pixel-level alignment so that 2-D gels with secondary stained images including antibodies can be directly compared.

\section{In-gel digestion}

Protein spots were excised from gels and de-stained with a solution containing $25 \mathrm{mM} \mathrm{NH} \mathrm{NCO}_{3}, 5 \% \mathrm{ACN}$ for $30 \mathrm{~min}$ and $25 \mathrm{mM} \mathrm{NH} \mathrm{NHCO}_{3} \quad 50 \%$ ACN twice for $30 \mathrm{~min}$. After dehydration in $100 \% \mathrm{ACN}$ for $10 \mathrm{~min}$, the spots were dried. Briefly, $100 \mathrm{ng}$ of chymotrypsin (Sigma, St. Louis, MO, USA), solution in Tris- $\mathrm{HCl} 100 \mathrm{mM}, \mathrm{pH}$ $7.8, \mathrm{CaCl}_{2} 10 \mathrm{mM}$ was added to the spots and digestion was performed at $37^{\circ} \mathrm{C}$ for $4-5 \mathrm{~h}$. After centrifugation, peptides were extracted by adding $8 \mu \mathrm{L}$ of ACN.

\section{Nano-LC-MS/MS analysis and database searching}

For Nano-LC-ESI-MS/MS analysis, peptides mixtures were analyzed by online nanoflow liquid chromatography using the Ultimate 3000 RSLC (Dionex, Voisins le Bretonneux, France) with nanocapillary columns of $15 \mathrm{~cm}$ length $\times 75 \mu \mathrm{m}$ ID, $3 \mu \mathrm{m}, 100 \AA$ (Acclaim PepMap100 C18, Dionex). The solvent gradient increased linearly from 4 to $50 \%$ acetonitrile in $0.5 \%$ formic acid at a flow rate of $300 \mathrm{~nL} / \mathrm{min}$ for $30 \mathrm{~min}$. The elute was then electrosprayed in positive-ion mode at $2.7 \mathrm{kV}$ in a LTQ-VELOS mass spectrometer (Thermo Fisher Scientific, Courtaboeuf, France) through a nanoelectrospray ion source which was operated in a CID top 10 mode (i.e. one full scan MS and the 10 major peaks in the full scan were selected for MS/MS). Full-enhanced-scan MS spectra were acquired with 1 microscan $(m / z 300-1,800)$. Dynamic exclusion was used with one repeat count and $50 \mathrm{sec}$ exclusion duration. For MS/MS, isolation width for ion precursor was fixed at $2 \mathrm{~m} / \mathrm{z}$, and single-charged species were rejected; fragmentation used $37 \%$ normalized collision energy as the default activation of 0.25 .

\section{Protein and peptide sequence analysis}

Raw data files were processed using version Peaks 5.3 software with the EBI database (Taxonomy Viridiplantae, 1,023,819 entries). The following parameters were considered for the searches: Parent Mass Error Tolerance of 1.5 Da, Fragment Mass Error Tolerance of 0.8 Da, a maximum of one missed cleavage, and partial methionine oxidation and partial carbamidomethylation of cysteine. If the peaks score was statistically significant $(p<0.05)$, the protein was considered valid. When proteins were 
identified from only two peptides, spectra were checked to assess their validity.

Synthesis of peptides

Different peptides derived from avenin sequences obtained from the MS/MS data (Table 1) were supplied by Biomedal S.L. (Seville, Spain).

\section{DC from peripheral blood}

Human peripheral blood was collected from three $\mathrm{HC}$ with no known autoimmune or inflammatory diseases, allergies, or malignancies and three patients with $\mathrm{CD}$ following informed consent. All CD patients had been on a GFD for at least 6 months and had no clinical symptoms or positive serology at the time of sample taking. The study was approved by the ethic committee of St Thomas' Hospital, London (United Kingdom) and written informed consent was obtained.

Peripheral blood mononuclear cells (PBMC) were obtained by centrifugation over Ficoll-Paque Plus (Amersham Biosciences, Chalfont St. Giles, UK). Human blood-enriched DC were subsequently enriched following NycoPrep ${ }^{\mathrm{TM}}$ centrifugation of overnight cultured PBMC in complete medium Dutch modified RPMI 1640 (SigmaAldrich, Dorset, UK) containing $100 \mathrm{U} / \mathrm{mL}$ penicillin/ streptomycin, $2 \mathrm{mM}$ L-glutamine, $50 \mu \mathrm{g} / \mathrm{mL}$ gentamicin (Sigma-Aldrich), and 10\% fetal calf serum (TCS Cellworks, Buckingham, UK). This protocol has been characterized in detail in previous studies as a way to obtain fresh human blood-enriched DC (35-38). Blood-enriched DC were further cultured for $24 \mathrm{~h}$ in complete medium in the presence of oat peptides, 33-mer peptide, STp (peptide secreted by Lactobacillus plantarum) or LPS (lipopolysaccharide from Escherichia coli) (Sigma-Aldrich, St. Louis, MO, USA). The same molar concentration was used for all peptides to avoid the problem of epitope load between large and small peptides. Results were referred with a paired culture in basal medium which acted as an internal control.

\section{Proliferation assay}

Freshly obtained PBMC from HC were suspended in MiniMACs buffer (PBS containing 0.5\% BSA and $2 \mathrm{mM}$

Table 1. Peptides derived from avenin sequences

\begin{tabular}{ll}
\hline Peptide & \multicolumn{1}{c}{ Sequence } \\
\hline Gliadin-like avenins & \\
QL6 & QPQLQL \\
QQ6 & QPQLQQ \\
PVI0 & PYPEQQEPFV \\
EF27 & EQYQPYPEQQEPFVQQQPPFVQQEQPF \\
Glutenin-like avenins & \\
QL14 & QQPFMQQQPFMQPL \\
QM27 & QYQPYPEQQPFMQQQQPFMQPLLQQQM \\
\hline
\end{tabular}

EDTA). T-cells were enriched by depletion of CD14, CD19, and HLA-DR-positive cells with immunomagnetic beads (Miltenyi Biotech, Bisley, UK) following manufacturer's instructions. An average of $94.91 \% \pm 1.06$ (mean \pm SD) T-cells was obtained following enrichment. T-cells were labeled with $10 \mu \mathrm{M}$ 5-carboxyfluorescein diacetate succinimidyl ester (CFSE, Invitrogen Ltd, Paisley, UK) following manufacturer's instructions. CFSE-labeled T-cells $\left(4 \times 10^{5} /\right.$ well) were incubated for 5 days in U-bottomed 96-well microtiter plates with allogeneic blood DC at 0,1 , or $3 \%$. Cells were washed twice in FACS buffer, fixed with $1 \%$ paraformaldehyde in $0.85 \%$ saline, and stored at $4^{\circ} \mathrm{C}$ prior to acquisition.

\section{Flow cytometry and data analysis}

Cells were acquired on a FACSCantoII (BD Biosciences) flow cytometer (within $48 \mathrm{~h}$ ). Data were analyzed using WinList 5.0 software (Verity, Topsham, Maine, USA). The percentage of proliferating T-cells was assessed via CFSE dilution of viable cells based on their forward and size properties as previously described (11).

\section{Statistical analysis}

Results were analyzed in the GraphPad Prism statistical PC program (GraphPad Prism 6.0 Software, San Diego, CA) using two-way and one-way repeated measures ANOVA, and two-tailed paired tests. $P$-value $<0.05$ was considered significant.

\section{Results and discussion}

\section{Protein characterization in different oat varieties}

Protein fractions from six oat varieties previously described as potentially reactive for CD patients (29) were studied by SDS-PAGE. The purity of the oat seeds was tested by a visual examination, and PCR experiments discarded the presence of wheat, rye, and barley DNA in the samples. The protein patterns of these cereals were compared with those of gliadins (from wheat) and with a pre-stained molecular weight marker (Fig. 1a).

Proteins with a wide range of molecular weights ranging from $<20$ to $80 \mathrm{kDa}$ were found in all albumin fractions of the different cultivars. Oat albumins, which are considered to be primarily enzymes, are a minor component with values ranging from 1 to $12 \%$ of total protein (39). Nevertheless, most of the protein fraction from the oat grains was soluble in buffered salt solutions and thus classified as globulins (40). These proteins (Fig. 1a) were mainly of two families, the first ranging from 20 to $37 \mathrm{kDa}$, and the second grouping around $50 \mathrm{kDa}$. Globulins appeared with the same distribution in all cultivars studied. Opposed to wheat gliadins, which have a typical size range of $29-70 \mathrm{kDa}$, oat avenins were smaller in size ranging from 20 to $36 \mathrm{kDa}$ with weaker bands around $50-70 \mathrm{kDa}$. Another important feature of these proteins is 


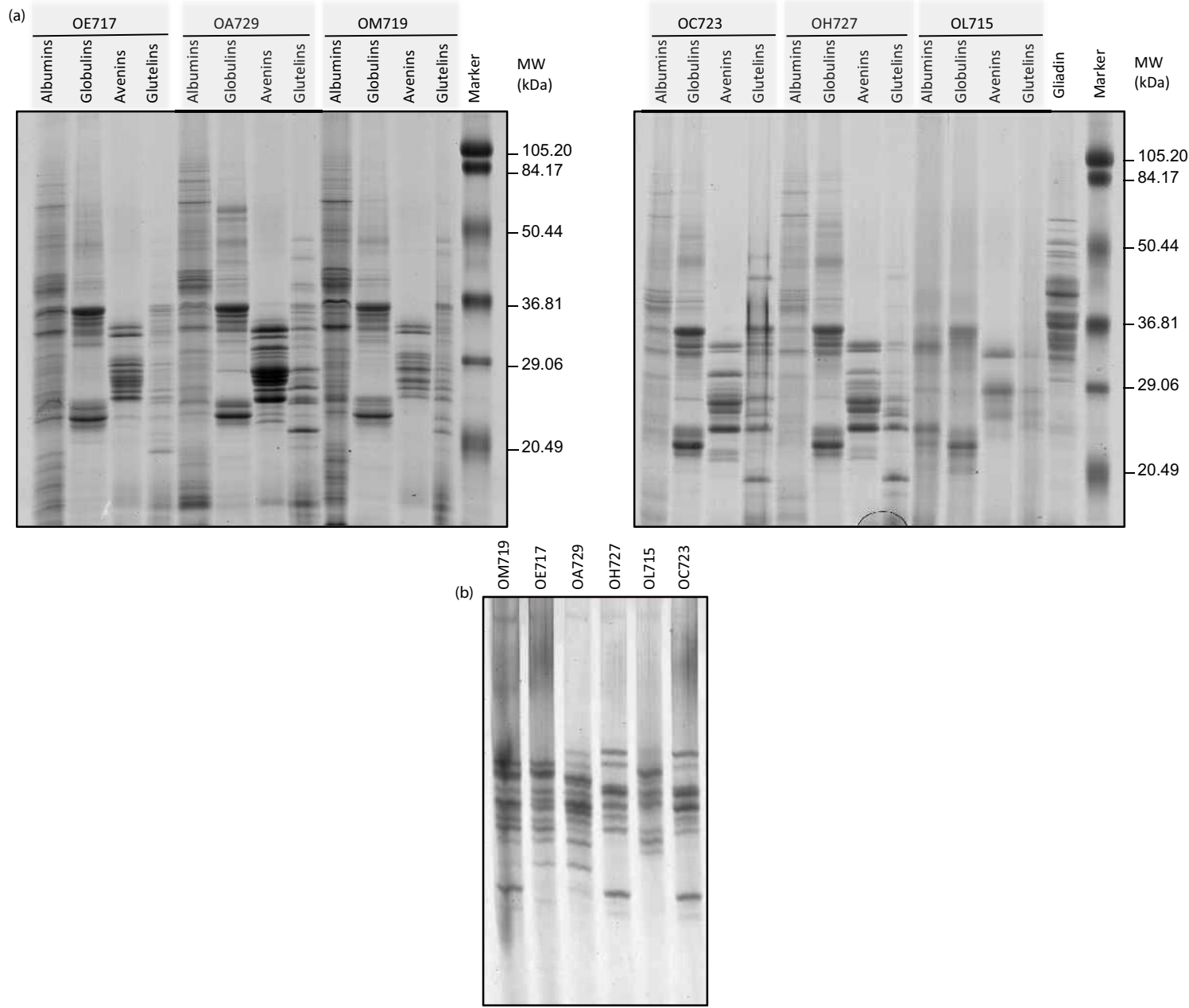

Fig. 1. Protein pattern from six oat accessions. (a) Oat proteins (albumins, globulins, avenins, and glutelins) were analyzed by SDS-PAGE using 12.5\% polyacrylamide gel and stained with Coomassie Brilliant Blue (CBB). (b) Avenins were analyzed by A-PAGE gel and stained with CBB. Oat accessions: OE717, OA729, OM719, OC723, OH727, and OL715. Lane MW, molecular weight markers (in $\mathrm{kDa}$ ).

that their protein patterns were diverse, confirming that polymorphism of avenin patterns was more heterogeneous than in the globulin fraction.

Concerning the glutenin fraction, a wide range in the molecular weight, ranging from 50 to even lower than 20 $\mathrm{kDa}$, was also observed for these proteins. For all other accessions, the glutenin protein patterns showed a diversity and heterogeneity in both size and intensity of the subunits. Our findings confirmed therefore that oat grains contain a significant protein fraction that is insoluble in alcohol and soluble in denaturing/reducing solution composed mainly of low molecular weight glutenin subunits (LMW-GS)-like proteins (41).

Because of the diversity found in the alcohol-soluble fractions, in order to identify the relative mobility of these proteins, an acid PAGE (A-PAGE) was performed. The diversity of cereal prolamins is usually better resolved by using electrophoresis in aluminum lactate buffer (such as in A-PAGE). Moreover, A-PAGE allows oat prolamins to be separated according to the ratio ionic charge/molecular mass resulting in a better resolution as compared to the classic SDS-PAGE procedure. A large number of avenin subunits were observed (Fig. 1b). Differences in the band patterns were found for the studied varieties, showing a great diversity in the composition of avenins among the different cultivars. These results therefore confirm the presence of different avenins in the cultivars as they differ in both their size and ionic charge in acid $\mathrm{pH}$. However, Spanish varieties OH727 and OC723 shared the same pattern of bands by A-PAGE. Likewise, two Australian accessions, OE717 and OM719, kept the same prolamin pattern but differed in two protein bands obtained in the lower region of the gel. These accessions probably have the same progenitors or related progenitors, or they may have independently evolved from accessions with small differences between them. 


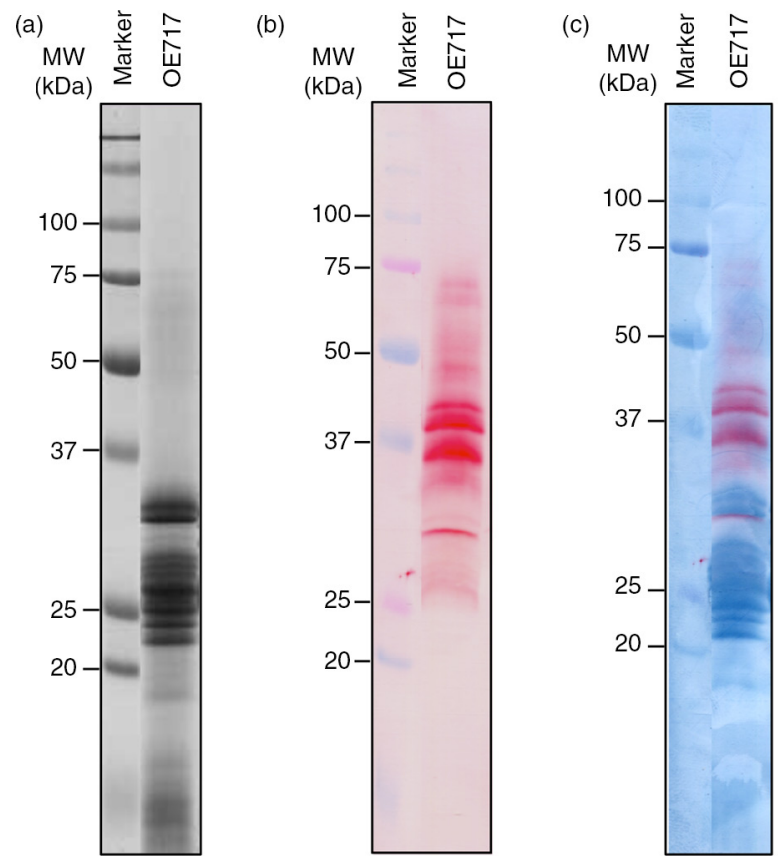

Fig. 2. Electrophoresis and immunoblot analysis of avenin protein extracts from oat accession OE717. (a) Proteins were separated by SDS-PAGE using $12.5 \%$ polyacrylamide gel and stained with Coomassie Brilliant Blue (CBB), (b) then transferred onto a nitrocellulose membrane and then exposed to G12 moAb. (c) Dual double membrane staining, first using G12 moAb and then nigrosin, distinguished the total avenin fraction versus G12-specific proteins. Lane MW, molecular weight markers (in $\mathrm{kDa}$ ).

\section{Evaluating immunotoxic proteins in the alcohol-soluble} fraction from oat seeds

In order to get further insights into the proteomic and immunological properties of the avenin proteins previously described, and their implications in CD pathogenesis, we focused on accession OE717 as it was described with high immunogenic effect of CD patients (29). The avenin extract from this accession was studied by western blot using

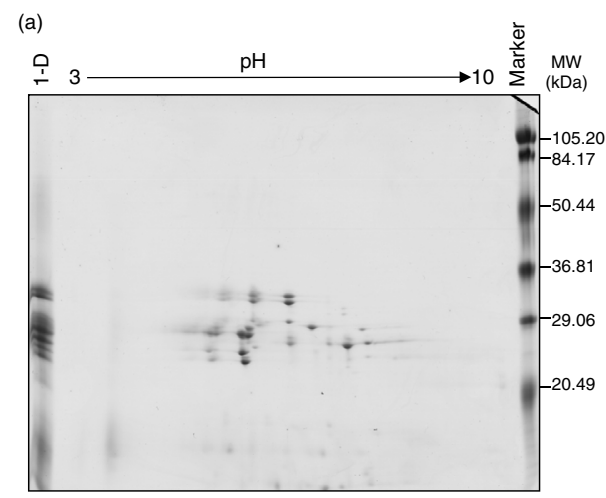

staining techniques which reveal in the membrane at the same time both the antibody-recognized proteins and the total proteins as separated by SDS-PAGE. A dual staining, first with the moAb and then nigrosin, distinguished the total avenin fraction versus specific proteins (Fig. 2). Reactive proteins appeared in the region of 25-37 $\mathrm{kDa}$ (major bands according to results obtained by SDSPAGE); however, anti-33-mer moAb also recognized other minority oat prolamins with higher molecular weights. The latter may be avenin dimers and/or oat prolamins not yet labeled with higher molecular weights.

When avenins from OE717 variety were separated in more detail by 2-DE, a single band on 1-DE typically yielded more than one protein spot (Fig. 3a). Avenin fraction was separated by $2-\mathrm{DE}$ and made visible by $\mathrm{CBB}$ staining. The 2-DE gels of these proteins revealed spots with relative molecular masses ranging from 35 to $20 \mathrm{kDa}$ and a $\mathrm{p} I$ between 3 and 10 . Figure $3 \mathrm{~b}$ showed proteome map obtained after immunoblotting by anti-33mer moAb. Immunoreactive spots were observed ranging from 40 to $25 \mathrm{kDa}$ on the western blot.

Among all the identified bands and spots, we next focused on the most reactive one as revealed by their immunoblotting intensity (Fig. 2b and $3 \mathrm{~b}$ ). Following overlaying of the nigrosin-stained membrane, the immunoblot and the corresponding $\mathrm{CBB}$ stained gel, bands (1-DE) and spots (2-DE) (as revealed by G12 moAb from the CBB stained gel) were excised and mass spectrometry analysis subsequently applied. A total of 16 reactive proteins were identified, all belonging to the family of prolamins, specifically avenin proteins (Table 2). We further confirmed by BLAST searches, using Multiple Protein Alignment Tool algorithms, that all the proteins identified belong to fractions previously termed $\alpha$ - and $\gamma$ gliadin-like. However, some bands and spots could not be identified due to lack of information from oat proteins in available databases.

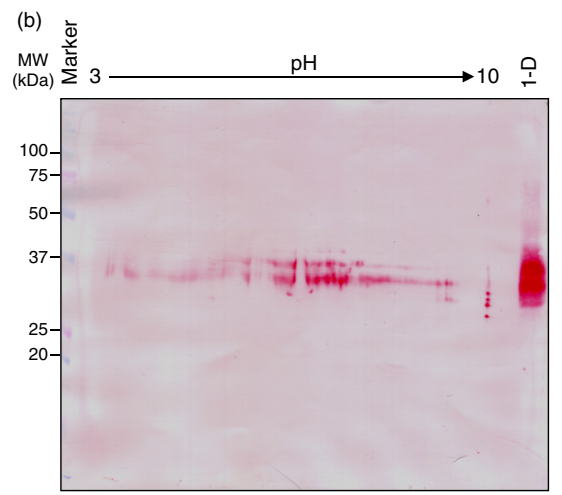

Fig. 3. Bi-dimensional analysis of avenin protein extracts from oat accession OE717. (a) Proteins were separated by isoelectric focusing (IEF) and SDS-PAGE, and then stained using Coomassie Brilliant Blue (CBB). (b) 2-D gel electrophoresis was transferred onto a nitrocellulose membrane and exposed to G12 moAb. Lane 1-D: avenin protein extract separated by SDSPAGE. Lane MW, molecular weight markers (in kDa). 
Table 2. List of identified proteins from 1-D and 2-D gels of avenin protein extract from oat accession OE717

\begin{tabular}{|c|c|c|c|c|c|}
\hline Sample $^{a}$ & Accession & Cov (\%) & Peptides & Mass & Description \\
\hline \multirow[t]{4}{*}{ A6 } & TR:G8ZCUI_9POAL & 60 & 4 & 27344.3008 & $\mathrm{G} 8 \mathrm{ZCUI}$ Avenin protein (Fragment) $\mathrm{OS}=$ Avena prostrata $\mathrm{GN}=$ avenin $\mathrm{PE}=4 \mathrm{SV}=\mathrm{I}$ \\
\hline & TR:G8ZCT4_9POAL & 59 & 4 & 29672.8789 & G8ZCT4 Avenin protein (Fragment) $\mathrm{OS}=$ Avena longiglumis $\mathrm{GN}=$ avenin $\mathrm{PE}=4 \mathrm{SV}=\mathrm{I}$ \\
\hline & TR:F2Q9W5_AVESA & 53 & 3 & 31613.2422 & F2Q9W5 Avenin protein (Fragment) $\mathrm{OS}=$ Avena sativa $\mathrm{GN}=$ avenin $\mathrm{PE}=4 \mathrm{SV}=\mathrm{I}$ \\
\hline & SP:AVEF_AVESA & 100 & 2 & 5213.6143 & Q09097 Avenin-F (Fragment) OS $=$ Avena sativa $\mathrm{PE}=\mathrm{I} \mathrm{SV}=\mathrm{I}$ \\
\hline \multirow[t]{15}{*}{ A7 } & TR:F2Q9W5_AVESA & 55 & 6 & 31613.2422 & $\mathrm{~F} 2 \mathrm{Q} 9 \mathrm{~W} 5$ Avenin protein (Fragment) $\mathrm{OS}=$ Avena sativa $\mathrm{GN}=$ avenin $\mathrm{PE}=4 \mathrm{SV}=\mathrm{I}$ \\
\hline & TR:Q09072_AVESA & 61 & 6 & 25471.4941 & Q09072 Avenin (Precursor) OS = Avena sativa PE $=2 \mathrm{SV}=\mathrm{I}$ \\
\hline & TR:G8ZCUI_9POAL & 57 & 6 & 27344.3008 & $\mathrm{G} 8 \mathrm{ZCU}$ Avenin protein (Fragment) $\mathrm{OS}=$ Avena prostrata $\mathrm{GN}=$ avenin $\mathrm{PE}=4 \mathrm{SV}=\mathrm{I}$ \\
\hline & TR:G8ZCTI_9POAL & 51 & 4 & 28834.0137 & $\mathrm{G} 8 \mathrm{ZCT}$ avenin protein (Fragment) $\mathrm{OE}=$ Avena strigosa $\mathrm{GN}=$ avenin $\mathrm{PE}=4 \mathrm{SV}=\mathrm{I}$ \\
\hline & SP:AVEE_AVESA & 66 & 3 & 21036.1562 & $\mathrm{Q} 09 \mathrm{I}$ I Avenin-E OS $=$ Avena sativa $\mathrm{PE}=\mathrm{I} \mathrm{SV}=\mathrm{I}$ \\
\hline & TR:G8ZCT5_9POAL & 53 & 4 & 28018.0723 & G8ZCT5 Avenin protein (Fragment) $\mathrm{OS}=$ Avena damascena $\mathrm{GN}=$ avenin $\mathrm{PE}=4 \mathrm{SV}=\mathrm{I}$ \\
\hline & TR:G8ZCT6_9POAL & 53 & 4 & 28018.0723 & G8ZCT6 Avenin protein (Fragment) $\mathrm{OS}=$ Avena strigosa $\mathrm{GN}=$ avenin $\mathrm{PE}=4 \mathrm{SV}=\mathrm{I}$ \\
\hline & TR:G8ZCT7_9POAL & 53 & 4 & 28018.0723 & G8ZCT7 Avenin protein (Fragment) $\mathrm{OS}=$ Avena canariensis $\mathrm{GN}=$ avenin $\mathrm{PE}=4 \mathrm{SV}=\mathrm{I}$ \\
\hline & TR:G8ZCV9_9POAL & 57 & 4 & 26660.6230 & G8ZCV9 Avenin protein (Fragment) $\mathrm{OS}=$ Avena murphyi $\mathrm{GN}=$ avenin $\mathrm{PE}=4 \mathrm{SV}=\mathrm{I}$ \\
\hline & TR:G8ZCW4_9POAL & 57 & 3 & 24318.9219 & G8ZCW4 Avenin protein (Fragment) $\mathrm{OS}=$ Avena macrostachya $\mathrm{GN}=$ avenin $\mathrm{PE}=4 \mathrm{SV}=\mathrm{I}$ \\
\hline & TR:F2Q9W3_AVESA & 52 & 2 & 25732.9043 & F2Q9W3 Avenin protein (Fragment) $\mathrm{OS}=$ Avena sativa $\mathrm{GN}=$ avenin $\mathrm{PE}=4 \mathrm{SV}=1$ \\
\hline & TR:G8ZCW2_9POAL & 16 & 2 & 23778.5078 & G8ZCW2 Avenin protein (Fragment) $\mathrm{OS}=$ Avena ventricosa $\mathrm{GN}=$ avenin $\mathrm{PE}=4 \mathrm{SV}=\mathrm{I}$ \\
\hline & TR:G8ZCW5_9POAL & 16 & 2 & 23778.5078 & G8ZCW5 Avenin protein (Fragment) $\mathrm{OS}=$ Avena murphyi $\mathrm{GN}=$ avenin $\mathrm{PE}=4 \mathrm{SV}=\mathrm{I}$ \\
\hline & TR:G8ZCV7_9POAL & 16 & 2 & 24500.3652 & G8ZCV7 Avenin protein (Fragment) $\mathrm{OS}=$ Avena magna $\mathrm{GN}=$ avenin $\mathrm{PE}=4 \mathrm{SV}=\mathrm{I}$ \\
\hline & TR:G8ZCV8_9POAL & 16 & 2 & 24500.3652 & G8ZCV8 Avenin protein (Fragment) $\mathrm{OS}=$ Avena mnurphyi $\mathrm{GN}=$ avenin $\mathrm{PE}=4 \mathrm{SV}=\mathrm{I}$ \\
\hline \multirow[t]{17}{*}{ A8 } & TR:G8ZCW3_9POAL & 52 & 6 & 27387.3730 & G8ZCW3 Avenin protein (Fragment) $\mathrm{OS}=$ Avena insularis $\mathrm{GN}=$ avenin $\mathrm{PE}=4 \mathrm{SV}=\mathrm{I}$ \\
\hline & TR:G8ZCT8_9POAL & 50 & 6 & 28205.2715 & G8ZCT8 Avenin protein (Fragment) $\mathrm{OS}=$ Avena canariensis $\mathrm{GN}=$ avenin $\mathrm{PE}=4 \mathrm{SV}=\mathrm{I}$ \\
\hline & TR:G8ZCT9_9POAL & 50 & 6 & 28205.2715 & G8ZCT9 Avenin protein (Fragment) $\mathrm{OS}=$ Avena strigosa $\mathrm{GN}=$ avenin $\mathrm{PE}=4 \mathrm{SV}=1$ \\
\hline & TR:F2Q9W5_AVESA & 45 & 6 & 31613.2422 & F2Q9W5 Avenin protein (Fragment) $\mathrm{OS}=$ Avena sativa $\mathrm{GN}=$ avenin $\mathrm{PE}=4 \mathrm{SV}=\mathrm{I}$ \\
\hline & TR:G8ZCUI_9POAL & 45 & 6 & 27344.3008 & $\mathrm{G} 8 \mathrm{ZCU}$ I Avenin protein (Fragment) $\mathrm{OS}=$ Avena prostrata $\mathrm{GN}=$ avenin $\mathrm{PE}=4 \mathrm{SV}=\mathrm{I}$ \\
\hline & TR:G8ZCU6_9POAL & 45 & 4 & 24307.0723 & G8ZCU6 Avenin protein (Fragment) $\mathrm{OS}=$ Avena prostrata $\mathrm{GN}=$ avenin $\mathrm{PE}=4 \mathrm{SV}=\mathrm{I}$ \\
\hline & TR:G8ZCT2_9POAL & 44 & 4 & 24435.2031 & $\mathrm{G} 8 \mathrm{ZCT} 2$ Avenin protein (Fragment) $\mathrm{OS}=$ Avena prostrata $\mathrm{GN}=$ avenin $\mathrm{PE}=4 \mathrm{SV}=\mathrm{I}$ \\
\hline & TR:F2Q9W4_AVESA & 48 & 4 & 24631.5215 & F2Q9W4 Avenin protein (Fragment) $\mathrm{OS}=$ Avena sativa $\mathrm{GN}=$ avenin $\mathrm{PE}=4 \mathrm{SV}=\mathrm{I}$ \\
\hline & SP:AVEE_AVESA & 52 & 4 & 21036.1562 & $\mathrm{Q} 09 \mathrm{I}$ I4 Avenin-E OS $=$ Avena sativa $\mathrm{PE}=\mathrm{I} \mathrm{SV}=\mathrm{I}$ \\
\hline & TR:Q09072_AVESA & 53 & 4 & 25471.4941 & $\mathrm{Q} 09072$ Avenin (Precursor) OS $=$ Avena satival $\mathrm{PE}=2 \mathrm{SV}=\mathrm{I}$ \\
\hline & TR:G8ZCW4_9POAL & 42 & 4 & 24318.9219 & G8ZCW4 Avenin protein (Fragment) $\mathrm{OS}=$ Avena macrostachya $\mathrm{GN}=$ avenin $\mathrm{PE}=4 \mathrm{SV}=\mathrm{I}$ \\
\hline & TR:F4MJYI_AVESA & 40 & 4 & 25600.3555 & $\mathrm{~F} 4 \mathrm{MJYI}$ Avenin protein (Fragment) $\mathrm{OS}=$ Avena sativa $\mathrm{GN}=$ avenin $\mathrm{PE}=2 \mathrm{SV}=\mathrm{I}$ \\
\hline & TR:G8ZCW0_9POAL & 37 & 4 & 26011.8594 & G8ZCW0 Avenin protein (Fragment) OS = Avena murphyi $\mathrm{GN}=$ avenin $\mathrm{PE}=4 \mathrm{SV}=1$ \\
\hline & TR:G8ZCU2_9POAL & 55 & 4 & $24 \mid 37.8320$ & $\mathrm{G} 8 \mathrm{ZCU} 2$ Avenin protein (Fragment) $\mathrm{OS}=$ Avena longiglumis $\mathrm{GN}=$ avenin $\mathrm{PE}=4 \mathrm{SV}=\mathrm{I}$ \\
\hline & TR:G8ZCU3_9POAL & 55 & 4 & 24137.8320 & $\mathrm{G} 8 \mathrm{ZCU} 3$ Avenin protein (Fragment) $\mathrm{OS}=$ Avena strigosa $\mathrm{GN}=$ avenin $\mathrm{PE}=4 \mathrm{SV}=\mathrm{I}$ \\
\hline & TR:G8ZCU4_9POAL & 55 & 4 & 24111.7949 & G8ZCU4 Avenin protein (Fragment) $\mathrm{OS}=$ Avena strigosa $\mathrm{GN}=$ avenin $\mathrm{PE}=4 \mathrm{SV}=1$ \\
\hline & TR:G8ZCU5_9POAL & 44 & 4 & 23093.7402 & $\mathrm{G} 8 \mathrm{ZCU} 5$ Avenin protein (Fragment) $\mathrm{OS}=$ Avena longiglumis $\mathrm{GN}=$ avenin $\mathrm{PE}=4 \mathrm{SV}=\mathrm{I}$ \\
\hline A9 & SP:AVE3_AVESA & 60 & 7 & 25275.4844 & P80356 Avenin-3 OS $=$ Avena sativa $\mathrm{PE}=\mathrm{I} \mathrm{SV}=\mathrm{I}$ \\
\hline
\end{tabular}


Table 2. (Continued)

\begin{tabular}{|c|c|c|c|c|c|}
\hline Sample ${ }^{a}$ & Accession & $\operatorname{Cov}(\%)$ & Peptides & Mass & Description \\
\hline & TR:Q2EPY2_AVESA & 65 & 7 & 24258.3320 & $\mathrm{Q} 2 \mathrm{EPY} 2$ Avenin $\mathrm{OS}=$ Avena sativa $\mathrm{PE}=4 \mathrm{SV}=\mathrm{I}$ \\
\hline & TR:G8ZCUI_9POAL & 51 & 6 & 27344.3008 & $\mathrm{G} 8 \mathrm{ZCUI}$ Avenin protein (Fragment) $\mathrm{OS}=$ Avena prostrata $\mathrm{GN}=$ avenin $\mathrm{PE}=4 \mathrm{SV}=\mathrm{I}$ \\
\hline & TR:G8ZCW3_9POAL & 54 & 6 & 27387.3730 & G8ZCW3 Avenin protein (Fragment) $\mathrm{OS}=$ Avena insularis $\mathrm{GN}=$ avenin $\mathrm{PE}=4 \mathrm{SV}=\mathrm{I}$ \\
\hline & SP:AVEE_AVESA & 66 & 5 & 21036.1562 & $\mathrm{Q} 09 \mathrm{I} \mid 4$ Avenin-E OS $=$ Avena sativa $\mathrm{PE}=\mathrm{I} \mathrm{SV}=\mathrm{I}$ \\
\hline & TR:Q09072_AVESA & 51 & 4 & $25471.494 \mid$ & Q09072 Avenin (Precursor) OS $=$ Avena sativa $\mathrm{PE}=2 \mathrm{SV}=1$ \\
\hline & TR:G8ZCV7_9POAL & 62 & 4 & 24500.3652 & G8ZCV7 Avenin protein (Fragment) OS $=$ Avena magna GN $=$ avenin $\mathrm{PE}=4 \mathrm{SV}=\mathrm{I}$ \\
\hline & TR:G8ZCV8_9POAL & 53 & 4 & 24500.3652 & G8ZCV8 Avenin protein (Fragment) $\mathrm{OS}=$ Avena murphyi $\mathrm{GN}=$ avenin $\mathrm{PE}=4 \mathrm{SV}=\mathrm{I}$ \\
\hline & TR:G8ZCU0_9POAL & 54 & 4 & 23039.7891 & G8ZCU0 Avenin pratein (Fragment) $\mathrm{OS}=$ Avena damascena $\mathrm{GN}=$ avenin $\mathrm{PE}=4 \mathrm{SV}=\mathrm{I}$ \\
\hline & TR:G8ZCW4_9POAL & 51 & 5 & 24318.9219 & $\mathrm{G} 8 \mathrm{ZCW} 4$ Avenin protein (Fragment) $\mathrm{OS}=$ Avena macrostachya $\mathrm{GN}=$ avenin $\mathrm{PE}=4 \mathrm{SV}=\mathrm{I}$ \\
\hline & TR:G8ZCW0_9POAL & 45 & 5 & 26011.8594 & G8ZCW0 Avenin protein (Fragment) $\mathrm{OS}=$ Avena murphyi $\mathrm{GN}=$ avenin $\mathrm{PE}=4 \mathrm{SV}=\mathrm{I}$ \\
\hline \multirow[t]{4}{*}{ ASI } & TR:G8ZCUI_9POAL & 57 & 10 & 27344.3008 & $\mathrm{G} 8 \mathrm{ZCU}$ I Avenin protein (Fragment) $\mathrm{OS}=$ Avena prostrataa $\mathrm{GN}=$ avenin $\mathrm{PE}=4 \mathrm{SV}=\mathrm{I}$ \\
\hline & TR:F2Q9W5_AVESA & 50 & 9 & 31613.2422 & F2Q9W5 Avenin protein (Fragment) $\mathrm{OS}=$ Avena sativa $\mathrm{GN}=$ avenin $\mathrm{PE}=4 \mathrm{~B} \mathrm{SV}=\mathrm{I}$ \\
\hline & TR:G8ZCTI_9POAL & 53 & 6 & 28834.0137 & $\mathrm{G} 8 \mathrm{ZCTI}$ Avenin protein (Fragment) $\mathrm{OS}=$ Avena strigosa $\mathrm{GN}=$ avenin $\mathrm{PE}=4 \mathrm{SV}=\mathrm{I}$ \\
\hline & SP:AVEF_AVESA & 84 & 3 & 5213.6143 & Q09097 Avenin-F (Fragment) OS $=$ Avena sativa $\mathrm{PE}=\mathrm{I} \mathrm{SV}=\mathrm{I}$ \\
\hline \multirow[t]{8}{*}{ AS3 } & TR:F2Q9W5_AVESA & 48 & 6 & 31613.2422 & F2Q9W5 Avenin protein (Fragment) $\mathrm{OS}=$ Avena sativa $\mathrm{GN}=$ avenin $\mathrm{PE}=4 \mathrm{SV}=\mathrm{I}$ \\
\hline & TR:G8ZCUI_9POAL & 50 & 6 & 27344.3008 & G8ZCUI Avenin protein (Fragment) $\mathrm{OS}=$ Avena prostrata $\mathrm{GN}=$ avenin $\mathrm{PE}=4 \mathrm{SV}=\mathrm{I}$ \\
\hline & TR:G8ZCW4_9POAL & 51 & 6 & 24318.9219 & $\mathrm{G} 8 \mathrm{ZCW} 4$ Avenin protein (Fragment) $\mathrm{OS}=$ Avena macrostachya $\mathrm{GN}=$ avenin $\mathrm{PE}=4 \mathrm{SV}=1$ \\
\hline & TR:F4MJYI_AVESA & 57 & 6 & 25600.3555 & $\mathrm{~F} 4 \mathrm{MJYI}$ Aveninl protein (Fragment) $\mathrm{OS}=$ Avena sativa $\mathrm{GN}=$ avenin $\mathrm{PE}=2 \mathrm{SV}=\mathrm{I}$ \\
\hline & TR:G8ZCW0_9POAL & 56 & 6 & 26011.8594 & G8ZCW0 Avenin protein (Fragment) $\mathrm{OS}=$ Avena murphyi $\mathrm{GN}=$ avenin $\mathrm{PE}=4 \mathrm{SV}=\mathrm{I}$ \\
\hline & TR:Q09072_AVESA & 55 & 4 & $2547 I .494 I$ & $\mathrm{Q} 09072$ Avenin (Precursor) $\mathrm{OS}=$ Avena sativa $\mathrm{PE}=2 \mathrm{SV}=\mathrm{I}$ \\
\hline & SP:AVEE_AVESA & 55 & 5 & 21036.1562 & $\mathrm{Q} 09 \mathrm{I} \mid 4$ Avenin-E OS $=$ Avena sativa $\mathrm{PE}=\mathrm{I} \mathrm{SV}=\mathrm{I}$ \\
\hline & SP:AVEF_AVESA & 67 & 3 & 5213.6143 & Q09097 Avenin-F (Fragment) OS $=$ Avena sativa $\mathrm{PE}=\mathrm{I} \mathrm{SV}=\mathrm{I}$ \\
\hline
\end{tabular}

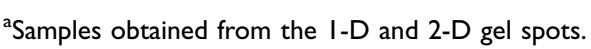



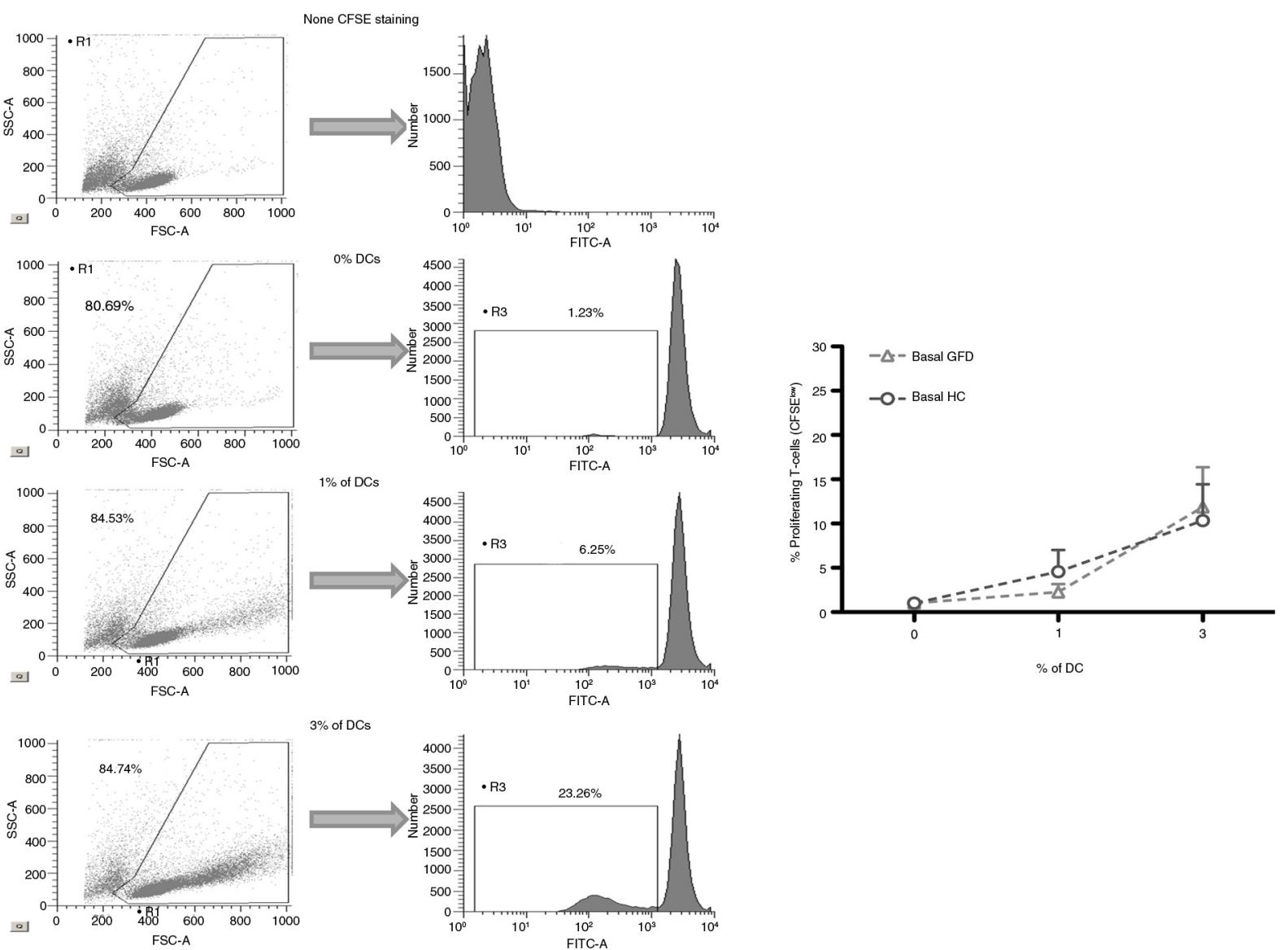

Fig. 4. Identification of dividing T-cells after dendritic cell stimulations. Blood CFSE-labeled T-cells (400,000) from healthy controls (HC) were cultured for 5 days with different doses $(0,1$, and 3\%) of allogeneic blood-enriched DC obtained from HC and gluten-free diet (GFD) coeliac disease patients. Live T-cells were subsequently identified by flow cytometry based on the forward (FSC-A) and side (SSC-A) scatter properties. DC stimulatory capacity was assessed based on T-cell proliferation determined via CFSE dilution (determined on the FITC channel) compared with unstimulated T-cells (cultured in the absence of DC). A second negative control included the culture of CFSE-negative T-cells. Histograms are representative of several independent experiments performed with similar results. Pooled results are displayed on the right plot.

Circulating $D C$ from $C D$ patients react to avenin peptides CD pathogenesis is driven both by the innate and the adaptive immune system $(1,4,42)$. Although the impact of gluten peptides on the adaptive immune system has been studied in much detail, the role of the innate immune response cells, including monocytes/macrophages and $\mathrm{DC}$, is still poorly understood.

DC are key actors in the connection between innate immunity and adaptive immunity responses. Furthermore, they are described as 'decision makers' to commit tolerance or immunity $(12,43)$, yet information on DC in CD pathogenesis is scarce $(8,44-47)$. Moreover, most of the studies which have investigated the effect of gliadin and/or its derived peptides on DC phenotype and/or function have usually focused on monocyte-derived DC, generated following 5-7 in vitro culture of monocytes in the presence of IL-4 and GM-CSF (48-53), which although essential to further our understanding of human DC do not always resemble the properties of circulating DC $(54,55)$.
Moreover, these studies usually focus on the effect of gliadin and/or its derived peptides on monocyte-derived DC from HC, usually avoiding a comparison with those obtained from CD patients. Contrary to those studies, here we decided to study the effect of these newly identified nowheat oat peptides on circulating DC obtained from both $\mathrm{HC}$ and $\mathrm{CD}$ patients.

To determine the stimulatory capacity of the novel oat peptides, DC were pulsed with peptides QL6, QQ6, PV10, EF27, QL14, and QM27 of different sizes that were found having a homology to gliadin-like avenins (Table 1) and glutenin-like avenins. These peptides had proline-rich sequences and glutamine residues resembling wheat gluten sequences. Peptides PV10 and EF27 also carried a T-cell epitope recognized by $\mathrm{CD} 4^{+} \mathrm{T}$-cells previously described by Sollid et al. (56): DQ2.5-ave-1a epitope with glutamic acid to glutamine conversion at position 6 . As positive control for stimulation, DC were pulsed with 33-mer peptide, the immunodominant antigen for CD (57) or 


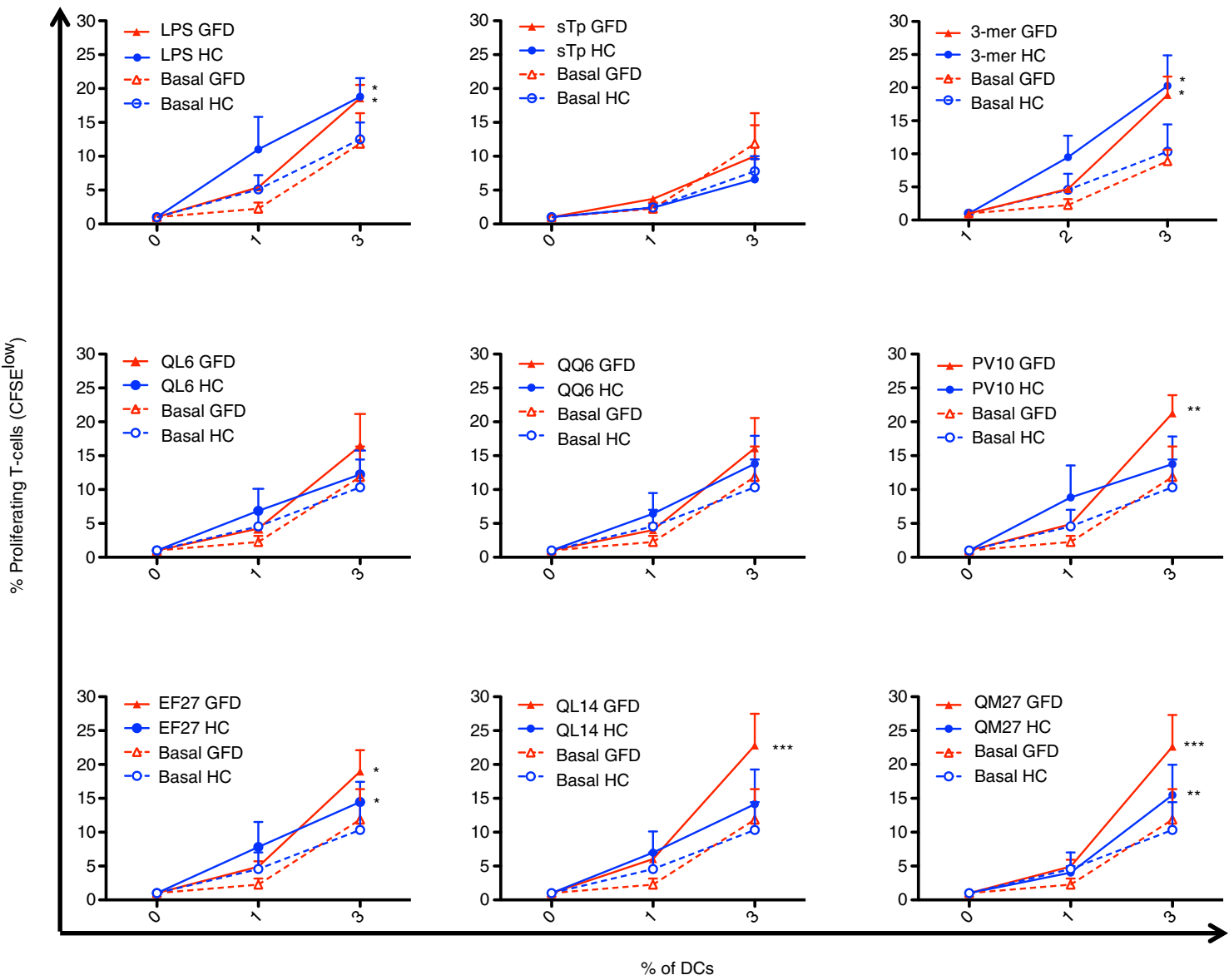

Fig. 5. Effect of oat peptides on the stimulatory capacity of DCs for allogeneic T-cells in CD. DC stimulatory capacity for CFSE-labeled allogeneic T-cells was determined as in Fig. 4. DC stimulatory capacity from both gluten-free diet coeliac patients (GFD, red lines) and healthy controls (HC, blue lines) was determined following 24-h pulsing with different stimuli as detailed in the graphs. Two-way ANOVA repeated was applied on pulsed DC (GFD or HC) compared with their basal paired counterparts. $P$-values $<0.05$ were considered as statistically significant $\left({ }^{*} p<0.05 ; * * p<0.01 ; * * * p 0.001\right)$.

with LPS. In addition to the basal (unstimulated) internal negative controls, DC were also pulsed with microbiotaderived STp, previously described to induce regulatory effects on DC in $\mathrm{HC}$ without affecting their stimulatory capacity (38).

In order to exclude any potential effect of the ongoing inflammation on the profile of circulating DC, and therefore on their peptide response following in vitro challenge, experiments were performed with blood-enriched DC from HC and GFD-CD patients with no clinical symptoms and negative serology at the time of blood extraction. Following antigen-pulsing and subsequent co-culture with $\mathrm{T}$ cells, DC from both HC and GFD-CD patients induced dose-dependent proliferative responses of CFSE-labeled allogeneic T-cells (determined as CFSE dilution by responding or dividing T-cells, Fig. 4) with no differential effect produced by blood DC from the groups irrespective of any differential basal stimulatory status between the groups.

The effect of the previously newly identified non-wheat oat peptides on DC from both HC and GFD-CD patients was studied next (Fig. 5). LPS increased stimulatory capacity of blood DC derived from both HC and GFDCD while STp did not induce any change in DC stimulatory status as previously described (Fig. 5) (38). When pulsed with the immunodominant 33-mer peptide, DC from both HC and GFD-CD patients increased their stimulatory capacity for T-cells in agreement with previous observations of an 'ex-vivo' gluten-challenge biopsyculture model (58). Having confirmed that in vitro pulsing modulates DC stimulatory capacity from both $\mathrm{HC}$ and GFD-CD patients, we studied whether the newly identified oat peptides displayed any differential effect on DC from the groups. Our findings revealed that oat peptides could be divided into three groups based on 1) their lack of stimulatory effect on DC (peptides QL6 and QQ6); 2) increase of DC stimulatory capacity from both HC and GFD-CD patients (peptides EF27 and QM27); and 3 ) peptides which specifically upregulated DC stimulatory capacity from GFD-CD patients but not from HC (peptides PV10 and QL14). A closer look into these oat peptides' properties revealed that peptides QL6 and QQ6 
(which did not have any stimulatory effect) were the smallest of the studied peptides (each with six residues). On the contrary, peptides EF27 and QM27 (which induced proliferative responses of T-cells stimulated by both $\mathrm{HC}$ and GFD-CD) were larger peptides (each with 27 residues); these peptides were of a size similar to the 33-mer peptide which had also activated DC from both $\mathrm{HC}$ and GFD-CD patients. This is in agreement with similar observations where large gliadin-derived peptides induced DC activation from non-CD patients $(49,50,52)$. Finally, peptides PV10 and QL14 were unique in their capacity to specifically activate DC from GFD-CD patients but not those from HC. In contrast to the two other groups, peptides PV10 and QL14 had intermediate sizes (PV10: 10 residues; QL14: 14 residues). These differences between the differential stimulatory capacity of the peptides on DC from HC and GFD-CD are not likely to be due to different epitope loads derived from their differential size as DC pulsing was performed at the same molar concentration. It seems, therefore, that DC capacity to trigger T-cell proliferative responses is not only dependent on the source of the peptides but also on their size and their possible differential intracellular processing. Thus, small peptides like QL6 and QQ6 (six residues each) would fail to activate DC while large gluten peptides (peptides EF27 and QM27 - of 27 and 33 residues, respectively) would induce DC maturation in both HC and GFD-CD. Nevertheless, gluten peptides with the appropriate size and disposition of amino acids-peptides PV10 (10 residues) and/or QL14 (14 residues) are likely to go through a differential endocytic pathway which may end in a different peptide processing capacity elicited by DC from $\mathrm{HC}$ and $\mathrm{CD}$ patients. Future studies will identify the specific mechanisms which make circulating DC form CD patients unique on their capacity to process and present these intermediate peptides to the T-cells, which may therefore provide valuable information for development of novel biomarkers for $\mathrm{CD}$ diagnosis and/or monitoring. Indeed, given that intestinal DC are likely to be derived from their circulating precursors (59) it is quite likely that intestinal DC will also display such differential processing capacity. If so, a deeper characterization of the differential peptide processing capacity elicited by intestinal DC from CD patients and non-CD controls may provide novel information regarding $\mathrm{CD}$ pathogenesis which may lead to development of novel therapies for such patients.

\section{Conclusions}

Our findings exhibited the structural complexity and large differences among oat proteins. More specifically, we showed that oats is composed of a large number of avenin subunits. These proteins belong to fractions termed $\alpha$ - and $\gamma$-gliadin-like and some of which were reactive for anti-33mer moAb. Moreover, our study has shown the existence of new potentially toxic peptides for coeliac patients. These peptides were able to activate circulating DC from coeliac patients, identifying, therefore, their immunogenic properties.

\section{Acknowledgements}

This study was supported by a grant (Project AGR172) from the Junta de Andalucía. IC was supported by the Contrato de Acceso al Sistema Español de Ciencia, Tecnología e Innovación para el Desarrollo del Programa Propio de I $+\mathrm{D}+\mathrm{i}$ from the Universidad de Sevilla and the EMBO short-term fellowship. DB and SCK were supported by the Biotechnology and Biological Sciences Research Council (BBSRC) Institute Strategic Programme for Gut Health and Food Safety BB/J004529/1. MS/MS analyses were realized by Christophe Chambon, PFEM, INRA Theix (France), to whom we are grateful.

\section{Conflict of interest and funding}

The authors have not received any funding or benefits from industry or elsewhere to conduct this study.

\section{References}

1. Jabri B, Sollid LM. Mechanisms of disease: immunopathogenesis of celiac disease. Nat Clin Pract Gastroenterol Hepatol 2006; 3: 516-25.

2. Makharia GK, Catassi C, Goh KL, Mulder CJ. Celiac disease. Gastroenterol Res Pract 2012; 2012: 758560.

3. Ludvigsson JF, Leffler DA, Bai JC, Biagi F, Fasano A, Green $\mathrm{PH}$, et al. The Oslo definitions for coeliac disease and related terms. Gut 2013; 62: 43-52.

4. Brandtzaeg P. The changing immunological paradigm in coeliac disease. Immunol Lett 2006; 105: 127-39.

5. Maiuri MC, De Stefano D, Mele G, Fecarotta S, Greco L, Troncone R, et al. Nuclear factor kappa B is activated in small intestinal mucosa of celiac patients. J Mol Med (Berl) 2003; 81: 373-9.

6. Maiuri L, Ciacci C, Auricchio S, Brown V, Quaratino S, Londei M. Interleukin 15 mediates epithelial changes in celiac disease. Gastroenterol 2000; 119: 996-1006.

7. Qiao SW, Bergseng E, Molberg Ø, Xia J, Fleckenstein B, Khosla $\mathrm{C}$, et al. Antigen presentation to celiac lesion-derived T cells of a 33 -mer gliadin peptide naturally formed by gastrointestinal digestion. J Immunol 2004; 173: 1757-62.

8. Ráki M, Tollefsen S, Molberg Ø, Lundin KE, Sollid LM, Jahnsen FLA. Unique dendritic cell subset accumulates in the celiac lesion and efficiently activates gluten-reactive $\mathrm{T}$ cells. Gastroenterol 2006; 131: 428-38.

9. Tollefsen S, Arentz-Hansen H, Fleckenstein B, Molberg O, Ráki M, Kwok WW, et al. HLA-DQ2 and -DQ8 signatures of gluten T cell epitopes in celiac disease. J Clin Invest 2006; 116: 2226-36.

10. Stagg AJ, Kamm MA, Knight SC. Intestinal dendritic cells increase $\mathrm{T}$ cell expression of alpha4beta7 integrin. Eur $\mathrm{J}$ Immunol 2002; 32: 1445-54.

11. Hart AL, Lammers K, Brigidi P, Vitali B, Rizzello F, Gionchetti $\mathrm{P}$, et al. Modulation of human dendritic cell phenotype and function by probiotic bacteria. Gut 2004; 53: 1602-9.

12. Bernardo D. Human intestinal dendritic cells as controllers of mucosal immunity. Rev Esp Enferm Dig 2013; 105: 279-90.

13. Norström F, Sandström O, Lindholm L, Ivarsson A. A glutenfree diet effectively reduces symptoms and healthcare consumption 
in a Swedish celiac disease population. BMC Gastroenterol 2012; 12: 125.

14. Nordyke K, Norström F, Lindholm L, Stenlund H. Healthrelated quality of life in adolescents with screening-detected celiac disease, before and one year after diagnosis and initiation of gluten-free diet, a prospective nested case referent study. BMC Public Health 2013; 13: 142.

15. Aziz I, Karajeh MA, Zilkha J, Tubman E, Fowles C, Sanders DS. Change in awareness of gluten-related disorders among chefs and the general public in the UK: a 10-year follow-up study. Eur J Gastroenterol Hepatol 2014; 26: 1228-33.

16. Singh R, De S, Belkheir A. Avena sativa (Oat), a potential neutraceutical and therapeutic agent: an overview. Crit Rev Food Sci Nutr 2013; 53: 126-44.

17. Koskinen O, Villanen M, Korponay-Szabo I, Lindfors K, Mäki M, Kaukinen K. Oats do not induce systemic or mucosal autoantibody response in children with coeliac disease. J Pediatr Gastroenterol Nutr 2009; 48: 559-65.

18. Fric P, Gabrovska D, Nevoral J. Celiac disease, gluten-free diet, and oats. Nutr Rev 2011; 69: 107-15.

19. Kaukinen K, Collin P, Huhtala H, Mäki M. Long-term consumption of oats in adult celiac disease patients. Nutrients 2013; 5: 4380-9.

20. Ciacci C, Ciclitira P, Hadjivassiliou M, Kaukinen K, Ludvigsson $\mathrm{JF}$, McGough N, et al. The gluten-free diet and its current application in coeliac disease and dermatitis herpetiformis. United Eur Gastroenterol J 2015; 3: 121-35.

21. Lundin KE, Nilsen EM, Scott HG, Løberg EM, Gjøen A, Bratlie J, et al. Oats induced villous atrophy in coeliac disease. Gut 2003; 52: 1649-52.

22. Arentz-Hansen H, Fleckenstein B, Molberg Ø, Scott H, Koning F, Jung G, et al. The molecular basis for oat intolerance in patients with celiac disease. PLoS Med 2004; 1: e1.

23. Tuire I, Marja-Leena L, Teea S, Katri H, Jukka P, Päivi S, et al. Persistent duodenal intraepithelial lymphocytosis despite a longterm strict gluten-free diet in celiac disease. Am J Gastroenterol 2012; 107: 1563-9.

24. Hollén E, Holmgren Peterson K, Sundqvist T, Grodzinsky E, Högberg L, Laurin P, et al. Coeliac children on a gluten-free diet with or without oats display equal anti-avenin antibody titres. Scand J Gastroenterol 2006; 41: 42-7.

25. Guttormsen V, Lovik A, Bye A, Bratlie J, Mørkrid L, Lundin KE. No induction of anti-avenin IgA by oats in adult, diet treated coeliac disease. Scand J Gastroenterol 2008; 43: 161-5.

26. Sjöberg V, Hollén E, Pietz G, Magnusson KE, Fälth-Magnusson $\mathrm{K}$, Sundström M, et al. Noncontaminated dietary oats may hamper normalization of the intestinal immune status in childhood celiac disease. Clin Transl Gastroenterol 2014; 5: e58.

27. Silano M, Di Benedetto R, Maialetti F, De Vincenzi A, Calcaterra R, Cornell HJ, et al. Avenins from different cultivars of oats elicit response by coeliac peripheral lymphocytes. Scand J Gastroenterol 2007; 42: 1302-5.

28. Silano M, Pozo EP, Uberti F, Manferdelli S, Del Pinto T, Felli $\mathrm{C}$, et al. Diversity of oat varieties in eliciting the early inflammatory events in celiac disease. Eur J Nutr 2014; 53: 1177-86.

29. Comino I, Real A, de Lorenzo L, Cornell H, López-Casado MÁ, Barro F, et al. Diversity in oat potential immunogenicity: basis for the selection of oat varieties with no toxicity in coeliac disease. Gut 2011; 60: 915-22.

30. Osborne TB. The proteins of the wheat kernel. Publication no. 84 Carnegie Institution of Washington. Washington, DC: Judd \& Detweiler; 1907.

31. Marion D, Nicolas Y, Popineau Y, Branlard G, Landry, J, editors. A new improved sequential extraction procedure of wheat proteins. In: Wheat Kernel Proteins-Molecular and Functional
Aspects. Viterbo, Italy: Universita Degli Studi della Tuscia, Consiglio Nationale delle Ricerche; 1994, pp. 197-199.

32. Singh NK, Shepherd KW, Cornish GB. A simplified SDSPAGE procedure for separating LMW subunits of glutenin. J Cereal Sci 1991; 14: 203-8.

33. Bradford MM. Rapid and sensitive method for quantitation of microgram quantities of protein utilizing principle of proteindye binding. Anal Biochem 1976; 72: 248-54.

34. Branlard G, Picard B, Courvoisier C. Electrophoresis of gliadins in long acrylamide gels: method and nomenclature. Electrophoresis 1990; 11: 310-14.

35. Ng SC, Plamondon S, Al-Hassi HO, English N, Gellatly N, Kamm MA, et al. A novel population of human CD56+ human leucocyte antigen D-related (HLA-DR + ) colonic lamina propria cells is associated with inflammation in ulcerative colitis. Clin Exp Immunol 2009; 158: 205-18.

36. Mann ER, Bernardo D, Al-Hassi HO, English NR, Clark SK, McCarthy NE, et al. Human gut-specific homeostatic dendritic cells are generated from blood precursors by the gut microenvironment. Inflamm Bowel Dis 2012; 18: 1275-86.

37. Bernardo D, Vallejo-Díez S, Mann ER, Al-Hassi HO, MartínezAbad B, Montalvillo E, et al. IL-6 promotes immune responses in human ulcerative colitis and induces a skin-homing phenotype in the dendritic cells and $\mathrm{T}$ cells they stimulate. Eur $\mathrm{J}$ Immunol 2012; 42: 1337-53.

38. Bernardo D, Sánchez B, Al-Hassi HO, Mann ER, Urdaci MC, Knight SC, et al. Microbiota/host crosstalk biomarkers: regulatory response of human intestinal dendritic cells exposed to Lactobacillus extracellular encrypted peptide. PLoS One 2012; 7: e36262.

39. Lásztity R. Oat grain: a wonderful reservoir of natural nutrients and biologically active substances. Food Rev Int 1998; 14: 99-119.

40. Klose C, Arendt EK. Proteins in oats; their synthesis and changes during germination: a review. Crit Rev Food Sci Nutr 2012; 52: 629-39.

41. Real A, Comino I, de Lorenzo L, Merchán F, Gil-Humanes J, Giménez MJ, et al. Molecular and immunological characterization of gluten proteins isolated from oat cultivars that differ in toxicity for celiac disease. PLoS One 2012; 7: e48365.

42. Bernardo D, Peña AS. Developing strategies to improve the quality of life of patients with gluten intolerance in patients with and without coeliac disease. Eur J Intern Med 2012; 23: 6-8.

43. Rescigno M, Di Sabatino A. Dendritic cells in intestinal homeostasis and disease. J Clin Invest 2009; 119: 2441-50.

44. Di Sabatino A, Pickard KM, Gordon JN, Salvati V, Mazzarella $\mathrm{G}$, Beattie RM, et al. Evidence for the role of interferon-alfa production by dendritic cells in the Th1 response in celiac disease. Gastroenterol 2007; 133: 1175-87.

45. Beitnes AC, Ráki M, Brottveit M, Lundin KE, Jahnsen FL, Sollid LM. Rapid accumulation of CD14 + CD11c+ dendritic cells in gut mucosa of celiac disease after in vivo gluten challenge. PLoS One 2012; 7: e33556.

46. Comino I, Šuligoj T, Al-Hassi HO, Lee GH, Sousa C, Landy J, et al. Constitutive gut-homing capacity on circulating myeloid dendritic cells in coeliac disease. Rev Esp Enferm Dig 2014; 106: $64-5$.

47. Schmitz F, Tjon JM, van Bergen J, Koning F. Dendritic cells promote expansion and survival of aberrant TCR-negative intraepithelial lymphocyte lines from refractory celiac disease type II patients. Mol Immunol 2014; 58: 10-16.

48. Nikulina M, Habich C, Flohé SB, Scott FW, Kolb H. Wheat gluten causes dendritic cell maturation and chemokine secretion. J Immunol 2004; 173: 1925-33.

49. Palová-Jelínková L, Rozková D, Pecharová B, Bártová J, Sedivá A, Tlaskalová-Hogenová $\mathrm{H}$, et al. Gliadin fragments induce 
phenotypic and functional maturation of human dendritic cells. J Immunol 2005; 175: 7038-45.

50. Cinova J, Palová-Jelínková L, Smythies LE, Cerná M, Pecharová B, Dvorák M, et al. Gliadin peptides activate blood monocytes from patients with celiac disease. J Clin Immunol 2007; 27: 201-9.

51. Rakhimova M, Esslinger B, Schulze-Krebs A, Hahn EG. In vitro differentiation of human monocytes into dendritic cells by peptic-tryptic digest of gliadin is independent of genetic predisposition and the presence of celiac disease. J Clin Immunol 2009; 29: 29-37.

52. Chladkova B, Kamanova J, Palova-Jelinkova L, Cinova J. Gliadin fragments promote migration of dendritic cells. Cell Mol Med 2011; 15: 938-48.

53. Giordani L, Del Pinto T, Vincentini O, Felli C, Silano M, Viora $\mathrm{M}$. Two wheat decapeptides prevent gliadin-dependent maturation of human dendritic cells. Exp Cell Res 2014; 321: 248-54.

54. Bernardo D, Mann ER, Al-Hassi HO, English NR, Man R, Lee $\mathrm{GH}$, et al. Lost therapeutic potential of monocyte-derived dendritic cells through lost tissue homing: stable restoration of gut specificity with retinoic acid. Clin Exp Immunol 2013; 174: 109-19.

55. Benlahrech A, Duraisingham S, King D, Verhagen L, Rozis G, Amjadi P, Ford T, et al. Human blood CD1c dendritic cells stimulate IL-12-independent IFN- $\gamma$ responses and have a strikingly low inflammatory profile. J Leukoc Biol 2015; 97: 873-85.

56. Sollid LM, Qiao SW, Anderson RP, Gianfrani C, Koning F. Nomenclature and listing of celiac disease relevant gluten T-cell epitopes restricted by HLA-DQ molecules. Immunogenetics 2012; 64: 455-60.

57. Tye-Din JA, Stewart JA, Dromey JA, Beissbarth T, van Heel DA, Tatham A, et al. Comprehensive, quantitative mapping of $\mathrm{T}$ cell epitopes in gluten in celiac disease. Sci Transl Med 2010; 2: 41 ra51.

58. Bernardo D, Garrote JA, Fernández-Salazar L, Riestra S, Arranz E. Is gliadin really safe for non-coeliac individuals? Production of interleukin 15 in biopsy culture from non-coeliac individuals challenged with gliadin peptides. Gut 2007; 56: 889-90.

59. Bernardo D, Durant L, Mann E, Bassity E, Montalvillo E, Man $\mathrm{R}$, et al. Chemokine (C-C Motif) receptor 2 mediates dendritic cell recruitment to the human colon but is not responsible for differences observed in dendritic cell subsets, Phenotype, and Function Between the Proximal and Distal Colon. CMGH Cellular Mol Gastroenterol Hepatol 2015; 2: 22-39.

\author{
*Carolina Sousa \\ Departamento de Microbiología y Parasitología \\ Facultad de Farmacia \\ Universidad de Sevilla \\ C/ Profesor García González, n2 \\ ES-41012 Sevilla \\ Spain \\ Email: csoumar@us.es
}

